\title{
ICE in dentistry: a medic's perspective
}

\author{
Helen Wall
}

\section{Key points}

Provides an example of a consultation tool (ICE) used commonly in the medical profession to improve patient and clinician satisfaction and opens discussion as to if and how dental professionals utilise this.
Details some insight into the pros and cons and examples of the ICE consultation tool for those who may not be fully aware of this method of communication.
Poses the question as to whether widespread utilisation of these skills from medicine across dentistry may help dental-patient relations, particularly in the upcoming challenging times.

\begin{abstract}
The consultation skill of eliciting a patient's ideas, concerns and expectations has been around in medicine since 1984. This article looks at what this skill may offer to dentistry and the challenges and benefits it may face.
\end{abstract}

ICE

The concept of eliciting a patient's ideas, concerns and expectations (ICE) was first discussed within the GP consultation model of Pendleton in 1984. ${ }^{1}$ It was later widened out to consulting with patients outwith general practice and, from the early 2000 s, some medical schools were starting to embed this way of consulting into their students' inner being (myself being one of them). This article looks at the benefits of ICE from a patient and clinician perspective, and challenges the common critique from my medical peers (especially new trainees) that it is too timeintensive to be beneficial, especially in the fast pace of an NHS clinic. Some readers may also consider how dental professionals communicate with their patients and whether framing communication around ICE as medics do would be helpful. Many dental professionals probably do this already but do not frame it as we do as 'ICE', and perhaps haven't reflected on the potential of this tool and its benefits to all.

As a GP married to a dental surgeon, I would often hear tales of patients who had undergone

${ }^{1}$ GP Partner, Trainer and Clinical Director for Commissioning, Bolton CCG, UK

Correspondence to: Helen Wall

Email address: helen.wall1@nhs.net

Refereed Paper.

Accepted 27 July 2020

https://doi.org/10.1038/s41415-021-2698-4 the most technically amazing piece of dental work but left unhappy - or worse, left and later reported they were unhappy - with the outcome. I could sense the disappointment and frustration time after time from many dental colleagues and friends. Not only had they spent copious amounts of time and effort providing what they felt to be (and probably was) great work, their skill was unappreciated and their days were being filled rectifying complaints.

I began to ask questions such as: what did the patient think their problem was when they came to see you? What did they believe was going to happen if left alone or treated? What was the root of their concern? What were they expecting to see and feel when they got home? I was often alarmed at how many highly skilled and intelligent professionals couldn't necessarily answer any of these questions, and moreover, very few (if any) thought that answering any of these would help their situation. When we reflect on ICE and the subsequent exploration of a patient's presentation, it becomes easy to see how it can be applied to most interactions in life and how a good salesperson may even adopt a similar technique to the mutual satisfaction of the customer and themselves.

As a GP, in my opinion, seeing a patient without eliciting ICE is like organising a decorator to paint your house without any instruction or dialogue whatsoever. You may have done lots of research into recommendations for a decorator and start happy with your decision. Yes, it will be decorated and it may look fresh and new, and it may be a technically perfect job, but if it wasn't what you expected, you realise it never needed doing in the first place - that wall still looks uneven through the new paint, and if it's painted in silk but you wanted functional and washable, it won't work for you. You will be left dissatisfied, you may complain and, worse still, you will probably tell everyone not to use that decorator. You certainly won't leave your precious home in their hands again or trust anything they have to say going forwards.

As a GP trainer, one of the greatest challenges I come across from my trainees is with regards to ICE; that it takes too much time which we haven't got, that it opens boxes we might not know how to close, that we can't provide what they want, that it sounds awkward to ask what the patient is expecting because, as the clinician, surely we should just know (Table 1). Over time as a GP registrar, the trainees go on a consultation ${ }^{2}$ journey and the ones who are likely to have the most satisfying career with the least patient complaints will come to realise that using ICE is an initial investment in time that pays dividends in the long run. In fact, once this skill has been learned and embedded, the real skill becomes deciding when to use it and to what end.

I challenge them and you to take any patient complaint and ask yourself: 'when I saw this patient, did I truly know what they believed was going on, what they were 


\begin{tabular}{|c|c|c|c|}
\hline ICE component & Examples & Benefits & Challenges \\
\hline Ideas & $\begin{array}{l}\text { 'What do you think might be } \\
\text { happening?' } \\
\text { 'What's your best guess as to what } \\
\text { is causing this?' }\end{array}$ & $\begin{array}{l}\text { Allows clinician to identify if the patient is assuming } \\
\text { it's something it can't possibly be and so they can } \\
\text { myth-bust } \\
\text { Allows clinician to establish a start point for any } \\
\text { subsequent explanation/bad news given }\end{array}$ & $\begin{array}{l}\text { If not done skilfully, the patient may feel you are } \\
\text { asking them as you don't know which can damage } \\
\text { trust } \\
\text { Can take time to myth-bust (this time likely gained } \\
\text { later on if patient understands start point) }\end{array}$ \\
\hline Concerns & $\begin{array}{l}\text { 'What's the worst thing you were } \\
\text { thinking it might be?' } \\
\text { 'What's your number one concern } \\
\text { regarding this problem at the } \\
\text { moment?' }\end{array}$ & $\begin{array}{l}\text { Often, what the patient is worried about is worse } \\
\text { than what you are dealing with; it allows clinician to } \\
\text { build trust and rapport } \\
\text { Allows clinician to tailor the solution to the patient's } \\
\text { concern - if you fix a problem without fixing the } \\
\text { patient's concern, the problem doesn't go away }\end{array}$ & $\begin{array}{l}\text { A more nervous patient may feel you are saying there } \\
\text { is something to be very concerned about } \\
\text { An upset patient may feel that, by asking them what } \\
\text { they are worried about, you are minimising their level } \\
\text { of worry which can damage rapport and trust }\end{array}$ \\
\hline Expectations & $\begin{array}{l}\text { 'What do you think might be the } \\
\text { best plan of action?' } \\
\text { 'What were you hoping would } \\
\text { happen today?' }\end{array}$ & $\begin{array}{l}\text { If you fix what you think the problem is and not what } \\
\text { the patient thought was needed, they will leave } \\
\text { unhappy. We don't have to meet their expectations } \\
\text { but it's helpful to explain why we are not/cannot } \\
\text { Allows clinician and the patient to get expectations } \\
\text { out on the table and manage them }\end{array}$ & $\begin{array}{l}\text { If not done carefully, patients can think you don't } \\
\text { know so are asking them for ideas which can affect } \\
\text { trust } \\
\text { You might discover you can't ever meet their } \\
\text { expectations which can be frustrating but better to } \\
\text { know sooner rather than later }\end{array}$ \\
\hline
\end{tabular}

worried about and what they expected?' The key is to remember that we don't need to agree with their ideas, feel their fears or necessarily meet their expectations, but we need to be able to recognise them, and sometimes even allow the patient time to recognise them and manage them. If you cannot do this well, they will leave still worried about something that was never actually an issue, believing they have a problem that isn't an actual problem or dissatisfied that what was provided isn't what they thought they'd have. Failing to address these issues is, in my opinion, the crux of most complaints and unhappiness for both the patient and clinician.
It appears that these communication skills have spread further over recent years to allied health professionals such as pharmacists. An article in Pharmacy magazine ${ }^{3}$ discusses how utilising the ICE technique turned around a pharmacist's ability to manage a patient's behaviour, seemingly improving the patient's outcomes and the experience of both the pharmacist and the patient. I'm sure many dental professionals are using these consultation skills knowingly or unknowingly, but I'd be interested to hear if reflecting on these skills as 'ICE' is helpful. I'm also aware that dental colleagues have hit very turbulent waters over recent months in the wake of a pandemic and recovery from this seems an epic challenge. All healthcare professionals are going to have to use every skill possible to develop patients' trust going forwards in the new COVID-19 world, whatever other priorities and worries we may have.

\section{References}

1. Pendleton D. The Consultation: an approach to learning and teaching. Oxford: Oxford University Press, 1984.

2. Harper C, Ajao A. Pendleton's consultation model: assessing a patient. BrJ Community Nurs 2010; 15: 38-43.

3. Barai R. ICE helped 'thaw' my consultations. 2015. Available at https://www.pharmacymagazine.co.uk/icehelped-thaw-my-consultations (accessed May 2020).

4. Potter L. Ideas, Concerns and Expectations (ICE). 2020. Available at https://geekymedics.com/ice/ (accessed July 2020). 